Bilingual Brokers 



\section{Bilingual Brokers}

RACE, LITERATURE, AND LANGUAGE AS HUMAN CAPITAL

Jeehyun Lim 


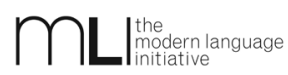

THIS BOOK IS MADE POSSIBLE BY A COLLABORATIVE GRANT

FROM THE ANDREW W. MELLON FOUNDATION.

Copyright (C) 2017 Fordham University Press

All rights reserved. No part of this publication may be reproduced, stored in a retrieval system, or transmitted in any form or by any means-electronic, mechanical, photocopy, recording, or any other-except for brief quotations in printed reviews, without the prior permission of the publisher.

Fordham University Press has no responsibility for the persistence or accuracy of URLs for external or third-party Internet websites referred to in this publication and does not guarantee that any content on such websites is, or will remain, accurate or appropriate.

Fordham University Press also publishes its books in a variety of electronic formats. Some content that appears in print may not be available in electronic books.

Visit us online at www.fordhampress.com.

Library of Congress Cataloging-in-Publication Data available online at http://catalog.loc.gov.

Printed in the United States of America

I9 I8 I7 5432 I

First edition 
for my mother, Young-hye Sung 
